\title{
Nuclear Receptor Coactivator 1
}

National Cancer Institute

\section{Source}

National Cancer Institute. Nuclear Receptor Coactivator 1. NCI Thesaurus. Code C17977.

Nuclear receptor coactivator 1 (1441 aa, $157 \mathrm{kDa}$ ) is encoded by the human NCOA1 gene. This protein is involved in the modulation of hormone-dependent transcription. 